\title{
Fish and Their Habitats in North-East India Biodiversity Hotspot
}

\author{
Devashish Kar* \\ Division of Wetlands and Fishery Science, Assam University, India
}

Submission: October 03, 2020; Published: February 04, 2021

Corresponding author: Devashish Kar, Division of Wetlands and Fishery Science, School of Life Sciences, Assam University, Conservation Forum, 39,Public School Road, Silchar Assam 788005 India

Abstract

Studies revealed rich biodiversity of fishes in North-East (NE) India biodiversity (BD) hotspot region. Fish habitats portrayed both lotic and lentic systems having different types of microhabitats and substrata in different stretches. Various limnological and ichthyological studies were done on Sone Beel wetland of national importance. Various studies were done on the zooplankton of different wetlands. Integrated Fish farming with fish and pigs have been found to a profitable venture. Occurrence of parasites have been reported from fishes in various wetlands. The dreadful EUS fish disease has been killing innumerable fishes of this region rendering many of them endangered. Attempts are being made to manage and conserve the fishes of the region through Community Based Fisheries Management (CBFM) involving the stakeholders from the grass root level.

Keywords: Fish diversity; Habitats; Rivers; Sone Beel wetland; Fish parasites; EUS; CBFM; North East India Biodiversity hotspot

\section{Introduction}

Various kinds of studies were done, since last four decades, on the Fishes and their habitats in the North-East (NE) region of India covering fish and non-fish biodiversity, aquaculture (AQC) and Fish disease. The wetlands and rivers were studied about their habitat inventory (HI). The NE India is a hotspot of biodiversity. The hills of this region give rise to many torrential hill streams, which lead to big rivers that finally become part of the GangaBrahmaputra-Barak-Chindwin-Kolodyne-Gomati-Meghna system [1]. Studies from 1979 to 2019 in the major rivers of Mizoram, Tripura and Barak drainage, revealed the occurrence of 42,42 , $31,25,36,9,14,23$ species of fishes in rivers Tuirial, Kolodyne, Karnafuli, Mat, Tlawng, Tuirini, Serlui and Tuivai respectively in Mizoram 28 22, 53 and 22 ichthyospecies in rivers Manu, Khowai, Gomati, and Feni respectively in Tripura and 65, 61, 54 and 32 species of fishes in rivers Barak, Jatinga, Sonai and Dhaleswari respectively in Assam [2].

HI parameters of the rivers revealed mostly 'fall', 'cascade' 'riffle-pool' types of micro-habitats mainly in their upstream rheophilic stretches in the hills; and, sometimes, in the midstream stretches. Accordingly, fall and cascade regions portrayed mostly bedrock and boulders, while the riffle-pool regions mainly depicted cobbles and gravels. These micro-habitats and substrata are important breeding grounds for the hill stream fishes, which have been undergoing irreparable losses due to human intervention and the fishes not finding a substratum for anchorage (with suckers, etc.), are often lost to oblivion being driven away by the fast torrents of the hill streams thus, causing colossal loss to the rheophilic biodiversity. Aquatic sanctuaries are essential in certain stretches of the rivers to protect the coveted fishes [2].

India has c 67,429 number of wetlands covering an area of c 4.1 million. The NE India Biodiversity (BD) hotspot region is blessed with several wetlands locally called 'Beel (perennial), Haor (seasonal floodplain) and Anua (river-formed oxbow type). These constitute $c 81 \%$ of the total lentic area $\left(0.12 \times 10^{6}\right)$ in Assam [1]. Sone Beel ( 3458.12 ha at FSL) situated at $23 \mathrm{~m} \mathrm{MSL}$ between $92^{\circ} 24^{\prime} 50^{\prime \prime}-92^{\circ} 28^{\prime} 25^{\prime \prime} \mathrm{E}$ and $24^{\circ} 36^{\prime} 40^{\prime \prime}-24^{\circ} 44^{\prime} 30^{\prime \prime} \mathrm{N}$ is one of the biggest wetlands in Asia. It has shallow plate-like basin and low volume development 0.15 , shore development $1.69, \ldots .$. etc. its shoreline $35.4 \mathrm{~km}$ gross volume $101.54 \times 10^{6} \mathrm{~m}^{3}$ and its mean depth $0.29 \mathrm{~m}$. Its area diminishes to 409.37 ha at DSL. Sone Beel has continuous inlet (max flow $33.91 \mathrm{~m}^{3} \mathrm{sec}^{-1}$ ) and outlet (max. flow $87.03 \mathrm{~m}^{3} \mathrm{sec}^{-1}$ ) channels. The latter acts as a spillway to limit retention of excess water storage. There is retention of higher silt load in the lake through the inlet ( $\max 350.0 \mathrm{mg} \mathrm{lit}^{-1}$ ) in contrast to low expulsion through the outlet (max. $216.0 \mathrm{mg} \mathrm{lit}^{-1}$ ). 
The turbidity ranged from $20.56 \mathrm{TU}$ to $185.54 \mathrm{TU}$. The overall thermal trend of the lake depicted a state of isothermy. The water temperature varied from 18.7 to $32.3{ }^{\circ} \mathrm{C}$, pH 6.02 to 7.9; DO 2.6 to $5.9 \mathrm{mg} \mathrm{lit.}^{-1}, \mathrm{FCO}_{2} 0.9$ to $14.5 \mathrm{mg} \mathrm{lit.}^{-1}$ and TA 25.0 to $76.0 \mathrm{mg}$ lit. $^{-1}$. The solubility of DO ranged from 9.4 to $11.9 \mathrm{mg} \mathrm{lit.}^{-1}$ while it $\%$ saturation varied from 32.3 to $74.4 \%$. As an index of dissolved salts, the conductivity of Sone water was low. The lake soil was quite unproductive with $\mathrm{pH}$ ranging from 5.02 to 5.9 , OC 0.25 to $1.74 \%$, available phosphorus ranging from 0.15 to $1.93 \mathrm{mg} 100$ $\mathrm{g}^{-1}$ and available potassium from 1.62 to $24.8 \mathrm{mg} 100 \mathrm{~g}^{-1}$. The phytoplankton depicted 47 forms with density varying from 10 to 5308 units lit $^{-1}$ The zooplankton contained 19 forms with density ranging from 6 to 380 units lit. $^{-1 .}$ The aquatic macrophytes (AM) biomass varied from 0.50 to $21.90 \mathrm{~kg} \mathrm{~m}^{-2}$. Eichhornia crassipes, Hydrilla verticillata and Trapa bispinosa were the perennial species. Among the littoral fauna, the piscian and non-piscian groups exhibited biomass from 0.05 to $1.53 \mathrm{~g} \mathrm{~m}^{-2}$ and $1.6 \times 10^{-4}$ to $1.09 \mathrm{~g} \mathrm{~m}^{-2}$ respectively [11].

There were 70 ichthyospecies belonging to 49 genera under 24 families. $84.2 \%$ belonged to primary freshwater group while the rest were of peripheral class. The total average annual fish yield (FY) from the wetland was 335.18 metric tons ( $\mathrm{mt}$ ); while the average per ha yield was $96.88 \mathrm{~kg}$. Puntius chola, contributed to an average Annual Relative Yield (ARY) of $24.60 \%$. The Indian Major Carps (IMC) depicted an average ARY of $0.73 \%$ The predatory fishes portrayed average ARY of $3.29 \%$ out of which, Wallago attu alone had portrayed average ARY of $2.94 \%$. The Indian shad, Hilsa (Tenualosa) ilisha, with an average ARY of 0.04 $\%$, revealed a single run during the monsoon against two in other water bodies of India. Of the four principal fishing communities of the lake classified into occasional, part-time, and professional types, the 'Kaibarta' community constituted $68 \%$ of the total fisherfolk and $55 \%$ of the Kaibarta fishermen were professional. Among the 26 varieties of fishing gears recorded, the CPGH (Catch person $^{-1}$ gear $^{-1}$ Hour $^{-1}$ Dey, 1981) of Mahajal was the highest (1.28 to $1.69 \mathrm{~kg}$ ) followed by Chinese dip net ( 0.53 to $0.93 \mathrm{~kg}$ ), long line ( 0.52 to $0.68 \mathrm{~kg}$ ), cage trap ( 0.21 to $0.56 \mathrm{~kg}$ ), and gill net ( 0.14 to $0.21 \mathrm{~kg})$.

Sone Beel was declared as a 'Wetland of National Importance' by the Government of India based on the research findings of the present author. (vide Resolution No. 11 dt. 16.10.2008, of MOEF Expert Group Meeting, New Delhi) [3] Our further study had portrayed 25 species of fishes in Dolu lake, 34 species in Chatla Haor, 40 species in Karbhala wetland in Assam and 31 species each in Awangsoi and Oinam wetlands, 33 species in Loktak wetland and 32 species in Utra wetland in Manipur [4]. Still further studies revealed that, E4 (Hills Evenness) and E5 (modified Hills Ratio) for Malini Beel and Narsingtola Pond portrayed an even distribution of zooplankton species (rotifers, cladocerans and copepods). Margoles diversity index revealed 6.66, 6.7, 6.43, 6.95 and 6.1; Shannon-weiner index revealed 1.97, 1.92, 2.08, 2.51 and 2.36; and Sheldon's index revealed 1.22, 1.28, 1.45. 1.67 and 1.7 respectively for Salchapra Anua, Madhura Anua, Sat Beel, Malini Beel and Narsingtola pond [5].

$\mathrm{AQC}$ has been an age-old practice among the fish farmers of the region. Integrated Fish Farming (IFF) practice involving Fish Culture with Livestock rearing holds great promise and potential for augmenting production of animal protein, betterment of economy and generation of employment in rural India. Studies were done on IFF practices in $4 \mathrm{IFF}$ farms each in villages Silcoorie (fishery with poultry) and Irongmara (fishery with piggery) in this region. Study revealed that, total annual profit in four IFs in village Silcoorie were Rs, 2, 40, 000.00; 3, 85, 000.00; 37,000.00 and 1, 40, 000.00 respectively while those in $4 \mathrm{IFs}$ in village Irongmara were Rs 53,084.00; 36, 486.50; 63,070.50; and 58,812.00, respectively. Studies revealed that, 22.72, 5.76 and $19.16 \%$ of the fishes in Dolu, Chatla Haor and Karbhala wetlands respectively in Assam; and 23.83,33.86, 49.75 and $48.8 \%$ of the fishes in Awangsoi, Oinam, Loktak and Utra wetlands in Manipur were parasitized by trematode, cestodes, nematodes and acanthocephalan parasites $[6,7]$.

Notwithstanding the above, EUS has been causing largescale mortality among the freshwater fishes since 1988, initially affecting four species of fishes very widely. Our study revealed fluctuation in the intensity of the disease in relation to species affected. Large haemorrhagic cutaneous ulcers, epidermal degeneration and necrosis followed by sloughing of scales are the principal symptoms of EUS. Low total alkalinity (TA) could be pre-disposing 'Stress factor'. Sick fishes show low haemoglobin and polymorphs, but high ESR and lymphocytes. Communicative nature of EUS revealed variation in time gap between fish and infection in different species. Inoculation of microbes in the test animals did not reveal of any sign of ulcerations for two years. Bacterial culture revealed occurrence of haemolytic E. coli, Aeromonas hydrophila, Pseudomonas aeruginosa, Klebsiella sp, Staphylococcus epidermitis in the surface lesions as well as in the gut, liver, gills, heart, kidney and gonads of sick fishes, all of which have been found to be sensitive to Chloramphenicol, Septran, Gentamycin, etc.

Fungal isolation revealed the occurrence of Aphanomyces sp with concomitant occurrence of the same fungal genus in histological sections of EUS-affected fishes. Histopathological (HP) studies showed focal areas of increased fibrosis and chronic inflammatory cell infiltration in muscles; focal areas of fatty deneeration of hepatocytes surrounding the portal triads in the liver. Inoculation of $10 \%$ tissue homogenate of EUSaffected Clarias batrachus into $80 \%$ confluent monolayer form BF2 and RTG fish cell lines in Leiboitz L-15 medium, revealed progressive CPE which was passable in subsequent cultures thus, indicating the 'isolation' of virus. Electron Microscopic studies with the ultra-thin sections of still-occurring EUS-affected fish tissues, revealed the presence of virus-like particles (inclusion bodies); and, preliminarily, the picobirna virus has been electron 
microscopically identified as the primary a etiological agent of EUS. Further studies in this regard are being conducted [8]. Recent studies revealed the detection of Ranavirus infection in cultivated carps of North-East India [9]. Attempts had been made to deal with management of water bodies and their fish resources through Community-Based Fisheries Management (CBFM). CBFM could be said to be a modus operandi to empower the community to manage their resources in a sustainable manner and to conserve the natural wealth for future [10].

\section{Conclusion}

Ichthyological surveys revealed rich diversity of fishes in rivers of NE India. However, there have been destruction of fish habitats Limnological studies portrayed usual trend of physicochemical parameters of water in the various wetlands. EUS have been devastating the fishes. Fish parasites have been adding to this dimension. However, Integrated fish farming and management of the resources by CBFM have been trying to improve the situation.

\section{References}

1. Kar D (2013) Wetlands and Lakes of the World. (1 $1^{\text {st }}$ Edn)., Springer, London, Pp. 687.

2. Kar D (2016) Wetlands, Rivers, Fish, Plankton resources and Fish disease and Aquaculture in North-East India: An Overview. Proceedings International Symposium Lake 37.
3. Kar D (1990) Limnology and Fisheries of Lake Sone in the Cachar district of Assam India. PhD Thesis, University of Gauhati, Assam 209213.

4. Kar D, Shomorendra M, Singha R, Puinyabati H, Geetarani B, et al. (2011) Fish diversity and Helminth fauna in the fishes of Assam and Manipur, India. Fishing Chimes 55-65.

5. Kar S, Kar D (2016) Studies on biodiversity and spatial distribution of rotifers, cladocerans and copepods in certain wetlands of Cachar district, Assam. Proceeding of International Symposium Lake 52.

6. Deb S (2007) Integrated Fish Farming in villages in Cachar district of Assam, India. MPhil dissertation, Assam University, Silchar, India 92.

7. Nath S (2015) Integrated Fish Farming in the rural areas in Cachar district of Assam, India. M.Sc dissertation, Assam University, Silchar, India, 120.

8. Kar D (2015) Epizootic Ulcerative Fish Disease Syndrome. (1 $1^{\text {st }}$ Edn), Elsevier, Academic Press, USA, Pp. 293.

9. Riji John K, Rosalind M, Kar D, Md Mansoor, Kumar Mahesh, et al. (2016) Detection of Ranavirus infection in cultivated carps of NorthEast India. Fish Pathology 51: 66-74.

10. Barman R C, Kar D (2014) Concept definition and approaches of community-based Wetlands Fishers and management. In: Kar D (Ed.) Research Frontiers in Wetlands, Fishery and Aquaculture, Dominant Publishers and Distributors Pvt Ltd, New Delhi, India, Pp. 291-310.

Add:11. Kar D (2007) Fundamentals of Limnology and Aquaculture Biotechnology, Daya Publishing House, New Delhi, India Pp. 609.

This work is licensed under Creative Commons Attribution 4.0 Licens DOI: 10.19080/OFOAJ.2021.13.555856
Your next submission with Juniper Publishers will reach you the below assets

- Quality Editorial service

- Swift Peer Review

- Reprints availability

- E-prints Service

- Manuscript Podcast for convenient understanding

- Global attainment for your research

- Manuscript accessibility in different formats

( Pdf, E-pub, Full Text, Audio)

- Unceasing customer service

Track the below URL for one-step submission https://juniperpublishers.com/online-submission.php 